\title{
HUBUNGAN INDEKS MASSA TUBUH DENGAN KADAR GULA DARAH PUASA PADA PASIEN DIABETES MELITUS TIPE 2
}

\author{
The Relationship of The Body Mass Index With Fast Blood Sugar Levels \\ In Patients of Diabetes Mellitus Type 2 \\ Sevia Dwi Suryanti ${ }^{1}$, Anggi Tunjung $\operatorname{Raras}^{1 *}$, Cleonara Yanuar Dini ${ }^{1}$, \\ Adhe Hariani Ciptaningsih ${ }^{2}$ \\ ${ }^{1}$ Program Studi Profesi Dietisien Fakultas Kedokteran Universitas Brawijaya \\ ${ }^{2}$ RSUD Dr Saiful Anwar Malang \\ *Email Korespondensi: anggitunjungr@gmail.com
}

\begin{abstract}
ABSTRAK
Status gizi lebih dapat menyebabkan resistensi insulin yang menyebabkan kadar gula dalam darah meningkat dan berpengaruh buruk pada jaringan serta dapat menimbulkan komplikasi. Kadar gula darah dapat diukur, salah satunya menggunakan Gula Darah Puasa (GDP). Tujuan penelitian ini untuk mengetahui hubungan antara indeks masa tubuh dengan kadar gula darah puasa pada pasien diebetes melitus tipe 2 di Poli Gizi RSUD Dr Saiful Anwar Malang. Penelitian ini menggunakan rancangan observasional dengan pendekatan cross sectional. Populasi dari penelitian ini adalah seluruh pasien diabetes melitus tipe 2 di Poli Gizi RSUD Dr Saiful Anwar. Teknik sampel yang digunakan adalah Purposive Sampling dengan memperhatikan kriteria inklusi dan ekslusi, $\mathrm{n}=30$. Hasil penelitian menunjukkan kadar GDP normal 30\%, kadar GDP tinggi 70\%. Status gizi underweight 3,3\%, normal $30 \%$, overweight $23,3 \%$, obesitas $130 \%$, obesitas $213,3 \%$. Berdasarkan uji Spearman didapatkan hasil $\mathrm{p}$ value $=0,751(\mathrm{p}>0,05)$. Tidak ada hubungan antara indeks masa tubuh dengan kadar gula darah puasa pada penderita diabetes melitus tipe 2 .
\end{abstract}

Kata Kunci : IMT, Gula Darah Puasa, Diabetes Melitus tipe 2

ABSTRACT

Nutritional status can cause insulin resistance which causes increase blood glucose levels, adversely affect the tissues and can cause complications. Blood glucose levels can be measured uses Fasting Blood Glucose (GDP). This purposed of this research was conduted to see the relationship between body mass index with blood glucose levels in patients with type 2 diabetes mellitus in outpatient RSUD Dr Saiful Anwar Malang. This study used an observational design with a cross sectional approach. Population of this study were all patients with type 2 diabetes melitus in outpatient RSUD Dr Saiful Anwar. The sample technique used was Purposive Sampling by paying attention to inclusion and exclusion criteria, $n=30$. The results showed a normal GDP level 30\%, a high GDP level 70\%. Poor nutritional status $3.3 \%$, normal 30\%, overweight $23.3 \%$, obesity $130 \%$, obesity $213.3 \%$. Based on Spearman test obtained $p=0,751) p>0,05$ ) and $r=-0,60$. There is no relationship between body mass index and blood glucose levels in patient with type 2 diabetes mellitus.

Keywords : BMI, Fasting Blood Glucose, Type 2 Diabetes Mellitus 


\section{PENDAHULUAN}

Diabetes melitus masih perlu mendapatkan penanganan yang tepat dari segala aspek untuk menurunkan jumlah kejadian diabetes melitus. Dapat dilihat berdasarkan riskesdas tahun 2013 prevalensi diabetes melitus sebesar 1,5\% dan belum mengalami penurunan pada 2018 dengan prevalensi yang sama yaitu masih sebesar 1,5\%. Berdasarkan hasil riskesdas Tahun 2018 rata-rata prevalensi diabetes di Indonesia sebesar 1.017.290 juta jiwa. Jawa Timur menduduki peringkat keempat terbesar setelah DKI Jakarta, Yogyakarta, Kalimantan Timur dan Sulawesi Utara dengan prevalensi sebesar 151.878 ribu jiwa. Hasil tersebut menunjukkan bahwa prevalensi diabetes di Jawa Timur masih tergolong tinggi dibandingkan dengan rata-rata prevalensi diabetes di Indonesia (1).

Kenaikan berat badan merupakan salah satu gejala pasien Diabetes Melitus Tipe 2. Indeks massa tubuh (IMT) merupakan pengukuran status gizi yang dapat dipengaruhi oleh berat badan seseorang. Status gizi lebih dapat menyebabkan resistensi insulin. Hal ini berpengaruh pada peningkatan gula darah dan perburukan jaringan serta dapat menyebabkan komplikasi termasuk obesitas sentral karena lipolisis terhadap efek insulin ${ }^{(2)}$.

Responden yang digunakan untuk penelitian adalah pasien rawat jalan yang didiagnosis Diabetes Melitus Tipe 2 di Rawat Jalan Gizi RSUD Dr Saiful Anwar Malang. Responden yang digunakan adalah pasien rawat jalan karena pada pasien rawat jalan cenderung mengatur dietnya sendiri sehingga berpengaruh pada kadar gula darah. Lokasi penelitian yang digunakan adalah RSUD Dr Saiful Anwar Malang. Pemilihan lokasi bertujuan agar data yang dihasilkan lebih representatif, karena RSUD Dr Saiful Anwar Malang merupakan rumah sakit dengan tipe $\mathrm{A}$. Responden pada penelitian ini berjumlah 30 pasien, yang berasal dari Rawat Jalan Gizi RSUD Dr Saiful Anwar Malang. Responden yang dipilih yaitu pasien dengan diagnosis Diabetes Melitus Tipe 2 yang sudah menjalani pemeriksaan biokimia kadar gula darah puasa.

Penelitian bertujuan untuk mengetahui hubungan indeks masa tubuh dengan kadar gula darah puasa pada pasien diabetes melitus tipe 2 di Rawat Jalan Gizi RSUD Dr. Saiful Anwar Malang yang dinilai berdasarkan pengukuran berat badan dan tinggi badan pasien serta GDP yang didapat dari data rekam medis.

\section{METODE PENELITIAN}

Penelitian ini menggunakan rancangan observasional dengan pendekatan cross sectional. Populasi yang digunakan adalah seluruh pasien rawat jalan yang didiagnosis Diabetes Melitus Tipe 2 di Poli Gizi RSUD Dr Saiful Anwar Malang. Sampel yang digunakan merupakan pasien rawat jalan yang didiagnosis Diabetes Melitus Tipe 2 di Poli Gizi RSUD Dr Saiful Anwar Malang dengan memperhatikan inklusi dan ekslusi. Teknik pengambilan sampel yang digunakan adalah Teknik Purposive Sampling dengan memperhatikan kriteria inklusi dan ekslusi. Data yang digunakan adalah data sekunder yang diambil dari rekam medis pasien berupa data GDP dan IMT. Hasil pengukuran indeks masa tubuh dengan kadar glukosa darah puasa dianalisa secara statistik dengan taraf kepercayaan 95\% $(\alpha=0,05)$ dan tingkat signifikansi $0,05 \quad(p=0,05)$. Uji normalitas menggunakan saphiro wilk. Didapatkan data terdistribusi tidak normal sehingga menggunakan analisis uji spearman yang dapat digunakan untuk melihat apakah ada hubungan yang antara indeks masa tubuh dengan kadar glukosa darah puasa pada pasien diabetes mellitus tipe II di Poli Gizi RSUD Dr Saiful Anwar Malang. Penelitian ini telah memperoleh keterangan kelaikan etik dengan No: 400/111/K.3/302/2019 dari Komite Etik Penelitian Kesehatan RSUD Dr Saiful Anwar Malang.

\section{HASIL PENELITIAN}

\section{Karakteristik Umum Responden Penelitian}

Jumlah responden yang ada pada penelitian ini sebesar 30 pasien. Berdasarkan tabel 1 menunjukkan data jenis kelamin responden, responden terbanyak terdapat pada pasien laki - laki yaitu 53\%, sedangkan sedangkan pada jenis kelamin perempuan sebesar 47\%. Menurut karakteristik responden berdasarkan usia, paling banyak responden pada usia dengan rentang 50-64 tahun yaitu sebesar $67 \%$, sedangkan paling sedikit terdapat pada rentang usia $>80$ tahun yaitu sebanyak $3 \%$.

Berdasarkan data yang ditunjukkan pada tabel 2 menurut distribusi IMT, responden terbanyak pada status gizi obesitas 1 dan normal, masing- masing sebesar 30\% sedangkan paling sedikit pada status gizi underweight sebesar 
$3,3 \%$. Menurut distribusi responden berdasarkan kadar gula darah

Tabel 1. Karakteristik Umum Responden

\begin{tabular}{|c|c|c|}
\hline Karakteristik & n & $\%$ \\
\hline \multicolumn{3}{|l|}{ Jenis Kelamin } \\
\hline Perempuan & 14 & 47 \\
\hline Laki - laki & 16 & 53 \\
\hline \multicolumn{3}{|l|}{ Umur } \\
\hline $30-49$ & 5 & 17 \\
\hline $50-64$ & 20 & 67 \\
\hline $65-80$ & 4 & 13 \\
\hline$>80$ & 1 & 3 \\
\hline Jumlah & 30 & 100 \\
\hline
\end{tabular}

Sumber: Data Terolah, 2019

Tabel 2. Distribusi Responden berdasarkan IMT dan Kadar Gula Darah Puasa

\begin{tabular}{lcc}
\hline \multicolumn{1}{c}{ Kategori } & n & \% \\
\hline Status gizi & & \\
Underweight & 1 & 3,3 \\
Normal & 9 & 30 \\
Overweight & 7 & 23,3 \\
Obesitas 1 & 9 & 30 \\
Obesitas 2 & 4 & 13,3 \\
\hline Kadar Gula Darah & & \\
$\quad$ Normal $(<126 \mathrm{mg} / \mathrm{dl})$ & 9 & 30 \\
Tinggi $(>126 \mathrm{mg} / \mathrm{dl})$ & 21 & 70 \\
\hline
\end{tabular}

Sumber: Data Terolah, 2019

Tabel 3. Hubungan Indeks Massa Tubuh dengan Kadar Gula Puasa

\begin{tabular}{lcccc}
\hline \multicolumn{1}{c}{ Status Gizi } & $\mathbf{n}$ & Normal & Tinggi & $\mathbf{p}$ \\
\hline Underweight & 1 & 1 & 0 & 0,751 \\
Normal & 9 & 3 & 6 & \\
Overweight & 7 & 1 & 6 & \\
Obesitas 1 & 9 & 2 & 7 & \\
Obesitas 2 & 4 & 2 & 2 & \\
\hline
\end{tabular}

Sumber: Data Terolah, 2019

\section{PEMBAHASAN}

\section{Karakteristik Umum Responden}

Mayoritas responden penelitian merupakan pasien dengan usia 38 - 81 tahun sebanyak 30 orang. Berdasarkan karakteristik responden menurut jenis kelamin didapatkan pasien perempuan sebesar $47 \%$ dan pasien laki laki sebesar 53\%. Dari data yang diperoleh responden yang terbanyak terdapat pada pasien laki-laki. Umur responden digolongkan menjadi 4 golongan, mayoritas berada pada rentang 50 64 tahun sebesar 67\%. Menurut (3) sebagian besar faktor penyebab teradinya Diabetes Melitus adalah faktor umur $\geq 45$ tahun.

\section{Distribusi Responden berdasarkan IMT dan Kadar Gula Darah Puasa}

Status gizi berdasarkan IMT menunjukkan bahwa mayoritas responden memiliki status gizi normal dan obesitas 1 yang masing - masing sebesar 30\%. "Status gizi merupakan ekspresi dari keadaan keseimbangan dalam bentuk variable tertentu atau perwujudan dari nutriture dalam bentuk variable tertentu" (4). Status gizi dipengaruhi oleh asupan makanan dan zat-zat gizi digunakan. Status gizi yang optimal merupakan keseimbangan antara asupan dan penggunaan zat gizi ${ }^{(5)}$. Berdasarkan kadar gula darah puasa pasien, sebagian besar menunjukkan kadar gula darah puasa yang tinggi $\geq 126 \mathrm{mg} / \mathrm{dl}$ sebesar $70 \%$ dan responden yang memiliki kadar gula darah puasa normal sebesar $30 \%$.

\section{Hubungan Indeks Massa Tubuh dengan Kadar Gula Puasa}

Status gizi responden menurut IMT yang didapatkan melalui pembagian berat badan dalam kilogram dengan tinggi badan dalam meter yang kemudian dikelompokkan menjadi status gizi underweight jika IMT $<18,5 \mathrm{~kg} / \mathrm{m} 2$, status gizi normal jika IMT dalam rentang 18,5$22,9 \mathrm{~kg} / \mathrm{m} 2$, status gizi overweight jika IMT $\geq 23$ $\mathrm{kg} / \mathrm{m} 2$, status gizi obesitas 1 jika IMT dalam rentang $25-29,9 \mathrm{~kg} / \mathrm{m} 2$, dan status gizi obesitas 2 jika IMT $\geq 30 \mathrm{~kg} / \mathrm{m} 2^{(6)}$. Pada hasil menunjukkan bahwa mayoritas responden mempunyai status gizi normal sejumlah 9 responden dengan pembagian sebanyak 6 responden mempunyai kadar gula darah tidak normal serta sebanyak 3 responden mempunyai kadar gula darah normal. Sejumlah 9 responden juga memiliki status gizi obesitas 1 dengan pembagian sebanyak 7 responden mempunyai kadar gula darah tidak normal dan sebanyak 2 responden mempunyai kadar gula darah normal. Pengukuran kadar gula darah puasa dikelompokkan dalam kategori normal apabila GDP $<126 \mathrm{mg} / \mathrm{dl}$ dan kategori tidak normal apabila $\geq 126 \mathrm{mg} / \mathrm{dl}$. Sebagian besar kadar gula darah responden pada kategori tidak normal yaitu sebesar $70 \%$. Kadar gula dalam darah yang tidak normal adalah kadar gula darah $\geq 126 \mathrm{mg} / \mathrm{dl}$ atau dapat juga disebut kadar gula darah yang tinggi. Kadar gula dalam darah yang tinggi biasa dimiliki oleh pasien dengan penyakit diabetes melitus.

Diketahui bahwa penderita diabetes melitus mayoritas mempunyai status gizi obesitas 1 dan normal. Pada pasien diabetes 
melitus dengan kadar gula dalam darah tinggi mempunyai status gizi obesitas 1 . Pada beberapa penelitian menyatakan bahwa diabetes melitus berakitan dengan obesitas. Penderita diabetes melitus dengan obesitas memilki pancreas yang menghasilkan insulin dalam jumlah cukup, kadar lemak yang tinggi pada pasien DM dengan obesitas mengakibatkan insulin tersebut tidak mampu bekerja secara maksimal. Kadar lemak yang tinggi menghambat penyerapan glukosa dalam tubuh ${ }^{(7)}$.

Analisis menggunakan uji Spearman yang dilakukan kepada 30 orang responden di Poli Gizi RSUD Dr. Saiful Anwar untuk mengetahui hubungan antara IMT dan GDP pada pasien diabetes melitus tipe 2. Hasil penelitian yang diperoleh yaitu menunjukkan nilai $\mathrm{p}>0,05$ $(0,751)$ yang memiliki arti tidak terdapat hubungan antara IMT dan kadar gula darah puasa pada pasien diabetes melitus tipe 2 di Poli Gizi RSUD Dr. Saiful Anwar. Data menunjukkan bahwa responden dengan kadar gula dalam darah tidak normal terbanyak terdapat pada status gizi obesitas tipe 1 sejumlah 7 orang dan disusul dengan status gizi overweight dan status gizi normal dengan masing-masing responden sejumlah 6 orang. Menurut Astuti C.M. (2013) menyatakan bahwa pengendalian kadar gula darah dipengaruhi oleh kepatuhan mengkonsumsi obat, kepatuhan diet, konsumsi lemak, pengetahuan terkait DM dan dukungan keluarga positif. Sehingga faktorfaktor tersebut dapat mempengaruhi normal atau tidak normalnya kadar gula darah seseorang disamping dari status gizi seseorang.

Hasil penelitian ini sesuai dengan penelitian yang pernah dilakukan oleh Dalawa F.N. (2013) yang menunjukkan bahwa tidak terdapat hubungan antara status gizi dengan kadar gula darah puasa yang dilakukan pada masyarakat kelurahan bahu kecamatan Malalayang Manado ${ }^{(8)}$. Penelitian yang oleh Dalawa, dkk (2013) memiliki persamaan dengan penelitian ini yaitu menggunakan desain observasional dengan rancangan cross sectional. Jurnal lain juga menyatakan bahwa tidak terdapat hubungan antara IMT dengan GDP dengan nilai $\mathrm{p}=0,121$ yang dilakukan pada siswa sekolah menengah atas (SMA) Negeri di wilayah Denpasar Utara ${ }^{(9)}$. Penelitian yang dilakukan Astuti, dkk (2018) memiliki persamaan dengan penelitian ini yaitu menggunakan desain observasional dengan rancangan cross sectional.

Namun penelitian ini tidak sejalan dengan penelitian yang dilakukan oleh Adnan M, dkk
(2013) yang menyatakan bahwa terdapat hubungan IMT dengan GDP penderita DM tipe 2 dengan nilai $\mathrm{p}=0,000$ atau $\mathrm{p}<0,05$ yang dilakukan di RS Tugurejo Semarang (10). Penelitian Adnan M, dkk (2013) memiliki pernyataan yang sama dilakukan oleh Masruroh E (2018) yang menyatakan bahwa terdapat korelasi antara status gizi dengan kadar gula darah pada penderita Diabetes Melitus tipe II di Poli Penyakit Dalam RSUD dr. Iskak Tulungagung tahun 2017 dengan $p$ value $=0,000$ (11). Penelitian oleh Adnan M, dkk (2013) memiliki perbedaan dengan penelitian ini dilihat dari jenis penelitian yang digunakan yaitu explanatory research dalam bidang gizi klinik dengan metode survey melalui pendekatan cross sectional. Populasi penelitian Adnan (2013) menggunakan semua pasien diabetes melitus tipe 2 rawat jalan. Sedangkan perbedaan yang dengan penelitian Masruroh E (2018) yaitu menggunakan desain penelitian analitik korelasional dengan pendekatan cross sectional. Pada penelitian Masruroh E (2018) populasi yang digunakan adalah semua penderita Diabetes Melitus yang datang berkunjung ke Poli Penyakit Dalam.

Status gizi lebih dapat mengakibatkan resistensi insulin. Hal ini menyababkan kadar gula darah meningkat dan memperburuk kondisi jaringan serta berdampak pada komplikasi termasuk obesitas sentral karena lipolisis terhadap efek insulin (2). Perbedaan hasil penelitian dapat disebabkan karena factor-faktor lain yang menyebabkan perbedaan status gizi serta kadar gula dalam darah.

Kadar gula darah dapat dipengaruhi oleh faktor seperti asupan lemak, kepatuhan mengkonsumsi minum obat, kepatuhan diet, pengetahuan tentang DM dan dukungan keluarga positif ${ }^{(9)}$. Kadar gula dalam darah dipengaruhi oleh kepatuhan minum obat berkaitan dengan kepatuhan pengelolaan penyakit, kepatuhan obat yang rendah akan berhubungan dengan tingginya kadar gula. Kepatuhan diet, asupan lemak dan pengetahuan berkaitan dengan pemilihan makanan yang berpengaruh terhadap asupan seseorang sehingga berdampak pada kadar gula darah darah. Dukungan keluarga juga turut berperan dalam pengelolaan diabetes yaitu salah satunya berkaitan dengan kepatuhan akan diet ${ }^{(9)}$.

Selain itu pola makan dan riwayat keturunan dapat mempengaruhi kadar gula darah seseorang ${ }^{(12)}$. Riwayat keturunan berpengaruh kepada kejadian diabetes melitus yang kemudian 
dapat menyebabkan kadar gula darah tinggi akibat keturunan yang kuat pada penderita diabetes melitus, seseorang yang memiliki saudara kandung dengan penyakit diabetes melitus cenderung beresiko yang lebih tinggi untuk terserang diabetes melitus ${ }^{(12)}$. Selain itu pola makan yang salah akibat konsumsi yang tidak sehat seperti konsumsi santan, lemak, ataupun gula berlebih dapat mempengaruhi kadar gula darah tinggi sehingga menyebabkan gangguan metabolisme ${ }^{(13)}$. Status gizi juga dapat dipengaruhi karena factor lain yaitu tingkat asupan seseorang (kualitas dan kuantitas makanan). Penelitian ini pada dasarnya bertujuan untuk melihat hubungan IMT dengan GDP pasien diabetes melitus tipe 2, sehingga terdapat keterbatasan penelitian yaitu tidak mengambil data lain terkait faktor yang berpengaruh pada kadar gula darah dan status gizi yang dapat berpengaruh pada penelitian ini.

\section{KESIMPULAN DAN SARAN}

Tidak ada hubungan antara IMT dengan GDP pada pasien Diabetes Melitus Tipe 2 di Poli Gizi RSUD Dr. Saiful Anwar.

\section{DAFTAR PUSTAKA}

1. Riskesdas. Badan Penelitian dan Pengembangan Kesehatan, Departemen Kesehatan, Republik Indonesia, Jakarta. In: Riset Kesehatan Dasar. Jakarta; 2018.

2. Suryani, Rosidina D, Christianto E. Gambaran Status Gizi Pasien Diabetes melitus Tipe 2 di Bangsal Penyakit Dalam RSUD Arifin Achmad Provinsi Riau. 2016.

3. Kekenusa J S. Analisis Hubungan Antara Umur dan Riwayat Keluarga Menderita DM Tipe 2 pada Pasien Rawat Jalan di Poliklinik Penyakit Dalam RSUP Prof. Dr Kandau Manado. J FKM Unsrat Manad. 2013;1(3).

4. Supariasa. Penilaian Status Gizi. In: EGC. Jakarta; 2014.

5. Almatsier S. Prinsip Dasar Ilmu Gizi. In: PT Gramedia Pustaka Utama. Jakarta; 2011.

6. Perkeni. Pengelolaan dan Pencegahan Diabetes Melitus Tipe 2 di Indonesia. In: KONSENSUS PERKENI. 2015.

7. Nangge M, Masi G, Oroh W. Hubungan Obesitas dengan Kejadian Diabetes Melitus di Wilayah Kerja Puskesmas Ranomut Kota Manado. e-Journal Keperawatan. 2018;6(1):1-6.

8. Dalwa F, Kepel B, Hamel R. Hubungan Antara Status Gizi dengan Kadar Gula Darah Pusasa pada Masyarakat Kelurahan Bahu Kecamatan Malalayang Manado. e-Journal Keperawatan. 2013;1(1):1-8.
9. Astuti AP, Dwipayana MP. Hubungan indeks massa tubuh (IMT) dengan kadar gula darah puasa pada siswa sekolah menengah atas (SMA) Negeri di wilayah Denpasar Utara. Ejournal Med Udayana. 2018;7(3):95-8.

10. Adnan M, Mulyati T, Isworo JT. Hubungan Indeks Massa Tubuh (IMT) Dengan Kadar Gula Darah Penderita Diabetes Mellitus (DM) Tipe 2 Rawat Jalan Di RS Tugurejo Semarang. J Gizi Unimus. 2013;2(1):18-24.

11. Masruroh E. Hubungan Umur dan Status dengan Kadar Gula Darah Penderita Diabetes Melitus Tipe II. J Ilmu Kesehat. 2108;6(2):153-63.

12. Rudi A, Kwureh HN. Faktor Resiko yng Mempengaruhi Kadar Gula Darah Puasa pada Pengguna Layanan Laboratorium. Wawasan Kesehat. 2017;3(2):33-9.

13. Depkes RI. Pedoman Praktis Memantau Status Gizi Orang Dewasa. Jakarta; 2010. 